\title{
Saudi Arabia and Saudi Women in Research Literature: A Critical Look
}

\author{
Rami F. Mustafa ${ }^{1} \&$ Salah $_{\text {Troudi }^{1}}$ \\ ${ }^{1}$ Graduate School of Education, University of Exeter, Exeter, UK \\ Correspondence: Rami F. Mustafa, Graduate School of Education, University of Exeter, Exeter, UK. E-mail: \\ mustafa.rami@gmail.com
}

Received: December 30, 2018

Accepted: Janaury 9, 2019

Online Published: January 30, 2019

doi:10.5539/ass.v15n2p133

URL: https://doi.org/10.5539/ass.v15n2p133

\begin{abstract}
The literature abounds with many researches and articles that are written in a way that portray the Kingdom of Saudi Arabia as the poster child of hegemony, essentialism and women oppression. In recent years, no aspect of Saudi Arabian society has been subject to more scrutiny and debate than the women's domain. Women's rights and responsibilities have been controversial issues among both conservatives and progressives in Saudi Arabia; nevertheless, Saudi women remain among the least studied population. This study draws on the academic and professional experiences of the author dealing with Saudi women in Canada, the UK, the USA and inside Saudi Arabia to further the critical scholarship on Saudi Arabia and Saudi women as site and population of academic research to avoid the essentialist, orientalist and Westernized understanding of Saudi Arabia and Saudi women. This article is a springboard to any researcher interested in studying - critically- Saudi women's issues.
\end{abstract}

Keywords: Saudi Arabia, Saudi Women, Islamic Feminism

\section{Introduction}

Part of the training of social researchers is to effectively scrutinize resources and critically reflect upon them. In our research, we have been baffled by the enormous amount of information and literature showing a non-critical conformity to the idea of Saudi Arabia as the cradle of essentialism, which included many scholarly works written by Saudis themselves. Al-Rasheed (2013) highlighted that a major impediment before researchers is the "limited historical knowledge about and current research on Saudi women" (p. 33) explaining that most research on the country focused primarily on history, politics, oils and Islamism. In the same vein, Al-Sudairy (2017) added that "Even when articles or studies are published, they tend to be written by people who lived abroad all their lives... or by Westerners who are unaware of the culture and customs known to Saudis" (p. 6). While we agree with Al-Rasheed (2013) and Al-Sudairy (2017); we would like to add that many scholarship on the country and Saudi women perpetuate the image of an oppressive regime and oppressed women. As researchers in the field of social studies, we are aware of the fact that many researchers, westerners and Saudis alike, tend to exploit certain literature to serve their purposes well; obscuring by that the other side of the coin. Nevertheless, many researchers do not have enough access to scholarship that discusses both sides.

The seed of this paper emanated from the encounter the co-author of this paper (Rami Mustafa) had with the external examiner for his viva. The examiner was skeptical of the literature presented in his thesis possibly because she was supervising Saudi male and female doctoral candidates who were portraying Saudi Arabia and Saudi women in a negative way. Nevertheless, our work revealed that most doctoral studies on Saudi Arabia or Saudi women neglect the other side of the coin, and rely mostly on what others say about Saudi Arabia. In this paper, we critically discuss several elements of Saudi Arabia and Saudi women's issues in an attempt to present a full picture for those interested in researching this arena.

\section{The Role of Religion in Saudi Arabia}

Islam and Saudi Arabia are closely intertwined and many scholars have commented on the close-knit relationship. Denman and Hilal (2011), for example, explained that "the Islamic religion is considered as much a part of the Saudi identity as the country's longstanding history as part of the greater Arab Peninsula" (p. 304). Moreover, Ochsenwald (1981) wrote: "In Saudi Arabia from its inception Islam has been the omnipresent and dominant factor in public life" (p. 274).

Saudi Arabia is considered as one of the most conservative and orthodox Muslim societies in the world. In fact, Saudi Arabia is the only Arab theocratic country where Islam is greatly intertwined with the government. The 
literature abounds with references to Wahhabism as the doctrine of Islam in Saudi Arabia. Wahhabism is a term used by different people to denote different ideas and specific reasons. Wahhabism is understood in two different ways. The first is usually pejorative, often intended as a slur. In that sense, Beydoun (2011) defined Wahhabism as a "textual interpretation hallmarked by its intolerance for other Islamic traditions and modernity" (p. 81). This definition of Wahhabism perpetuates the prevalent paradigms in the literature on Saudi Arabia being essentialist/social structuralist. This paradigm is represented mostly by governmental and masculine positions that see biology (being born a woman) and social structure (women's status and roles in Saudi Arabia) as the basis for their identity. Bucholtz (2003) explained that essentialism refers to:

"the position that the attributes and behavior of socially defined groups can be determined and explained by reference to cultural and/or biological characteristics to be inherent to the group. As an ideology, essentialism rests on two assumptions: (1) that groups can be clearly delimited, and (2) that group members are more or less alike." (p. 400)

The essentialist paradigm is forced upon women in Saudi Arabia by virtue of the Wahabi interpretation of shari'a laws that dictate all aspects of life in Saudi Arabia, and which have remained largely unchanged, and by the prescribed roles and assumptions dictated by a society that focuses on the role of Saudi women as mothers and wives (Miller-Rosser, Chapman, \& Francis, 2006). Yamani (2000) pointed out that "although interpretations of 'correct' Islamic behavior influence all sections of society, local customs, norms, and tribal traditions actually dictate women's roles and are enforced through familial structure" (p. 96). According to Doumato (2010), "...gender inequality is built into Saudi Arabia's governmental and social structures, and is integral to the country's state-supported interpretation of Islam, which is derived from a literal reading of the Koran and Sunna" (p. 425). Cooke (2007) created a neologism that captures this essentialism, "Muslimwoman, which refers to "an imposed identification the individual may or may not choose for herself. The Muslimwoman is not a description of reality, it is an ascription of a label that reduces all diversity to a single image" (p. 140).

In opposition to the image of Wahhabism as a deviant attempt to alter Islam (Oliver, 2004), scholars such as Delong-bas (2004) and Curtis (2010) believed that Wahhabism is a major reform movement in Saudi Arabia. Curtis (2010) and Zarabozo (2003) explained that the term Wahhabi was first used by outsiders; in particular, opponents of Ibn Abdul-Wahhab dawa ${ }^{1}$ to isolate his interpretation of Islam from other forms, and to denigrate his followers because they were not considered as followers of Islam, but of Ibn Abd al-Wahhab himself. The term that Ibn Abd al-Wahhab preferred to use was muwahiddun ${ }^{2}$ (Curtis, 2010, p. 571; Zarabozo, 2003, p. 157).

The debate over the definition of Wahhabism, and various other political, social, and economic factors has created three religious mainstreams: Islamic hardliners, pragmatic conservatives, and liberals. Alhargan (2012) defined the Islamic hardliners as "those who adopt religious views that are not entirely based on original Islamic texts, and principles [that] can be obstacles to the advancement of women's rights" (p. 131). Haas (2014) explained that hardliners also tend not to support the rights of religious minorities. Pragmatic conservatives who, according to Sahly (2016), are more educated than the hardliners and hold advanced degrees in Islamic jurisprudence and share the objectives of the hardliners; i.e., building a state based on Islamic law, but with a pragmatic sense. They push for creating modern and strong economies and communities within the confines of Islamic law. Members of this mainstream are usually found in the Council of Senior Scholars. The third mainstream is comprised of the Islamo-liberals who rose from Western liberalism and moderate religious leaders. Their efforts are focused on promoting societal reforms, egalitarian gender relations, recognition of rights, and representing a moderate version of Islam (Alhragan, 2012; Haas, 2014).

Saudi Arabia, that once adopted Wahhabi teachings beyond its theological nature to become the official and only basis for laws and conduct, is now slowly moving towards a modern state with fewer religious influences. The Saudi government has taken many steps to diminish extremism and promote moderation by appointing moderate scholars in the Council of Senior Scholars, taking initial steps to ease the sex segregation rules in public places, reconsidering the legal guardianship issue, and most recently allowing women to drive.

\section{Agentive Saudi Women}

Littrel and Bertsch (2013) categorize Saudi Arabia as a patriarchal belt society, where the law reinforces discrimination against females by limiting their freedoms. The authors succinctly captured the sociocultural nature of Saudi Arabia:

\footnotetext{
1 Dawa in Arabic means the "The Call of Islam".
}

2 Muwahiddun means monotheists or unitarians. 
"Societal practices institutionalise negative discrimination concerning women, often codified in laws that prohibit women from participating in much of public life or fully competing in the labour market ... The patriarchal belt is characterised by extremely restrictive codes of behaviour for women, such as the practice of rigid gender segregation and a powerful ideology linking family honour to female virtue. Men are entrusted with safeguarding family honour through their control over female members; they are backed by complex social arrangements that ensure the protection, restriction, and dependence of women" (Littrel \& Bertsch, 2013, p. 313).

The Saudi state, at least in the past 30 years or so, created an image of an "ideal woman," which was used later as a national symbol. Deo (2006) stipulated that women are seen as "bearers of their cultural traditions," so that "[d]efining women would allow a nation to define itself" (p. 106). Yamani (2005) explained that the state has used women's symbolic gesture to confirm its commitment to Islamic teachings; and therefore, strengthen its image as the birthplace of Islam. Part and parcel of that image is the widespread orientalist stereotype image of the Muslim woman as a passive and agentless victim and subject to ongoing injustices because of Islam. Nevertheless, we have to admit that this particular image, though widespread, has also been challenged in literature.

In opposition to that image, the Saudi women with whom we have worked and taught exercised great, and at times excessive, subjectivity and agency. The Saudi women interviewed by Mustafa's (2017) doctoral study can be subjectively described using Weedon's (1997) words as involving the conscious and unconscious thoughts and emotions of the individual, their sense of themselves, and their ways of understanding their relation in the world (p. 32). The sense of subjectivity develops an understanding of agency that Duff (2012) defines as "people's abilities to make choices, take control, self-regulate, and thereby pursue their goals as individuals leading, potentially, to personal or social transformation" (p. 417). That agency is not restricted only to their roles as wives and mothers, but it goes further and includes decisions about a number of matters such as pursuing a higher education overseas and seeking employment opportunities. Asserting their subjectivity and exercising their agency, many Saudi women have made it to the top tiers in governments that were once monopolized by men. Examples of this include the historical appointment of 30 Saudi women to the Shura Council (similar to the US Congress) in 2013, and the 20 Saudi women winning municipal elections in 2015. The year 2017 was of Saudi women for it witnessed the appointment of Princess Rima to head the Multi-Sport Federation, the naming of Fatima Baeshen as the spokesperson for the Saudi embassy in Washington, DC, choosing Hind Al-Zahid as the executive director of Dammam airport, and naming Sarah Al Suhaimi as head of the Saudi stock market (cf. Al-Sudairy, 2017).

\section{The Theoretical Framework}

Poststructuralism came to reconcile the structure-agency debate and poststructuralist scholars such as Giddens (1984) and Bourdieu (1984) vowed to show the dialectical relational nature of the 'structure' and 'agency', and the importance of considering both notions when trying to understand the social life and organization. Butler (2006) characterized agency as a socially situated, culturally bound process. From the previous section, the identities of individuals are mostly shaped by historical and social contexts, and by extension, "Socially constructed selves are not dupes but agents who act and resist" (Hekman, 2013, p. 21). Moreover, people have agency that helps shape these social and historical contexts. Ahearn $(2001,2012)$ provisionally defined agency as "the socioculturally mediated capacity to act" (2000, p. 112), though he also declared that this definition is not enough and is just a starting point, calling for further interrogation to reach a more nuanced definition.

Giddens (1984) connected agency to the notion of power, because "to be a human is to be an agent... and to be an agent is to have power" (p. 9). Within this context, power implies the individual's ability to perform an intended act. Influenced by sociocultural theorists, Vygotsky (1978), Bakhtin (1981), and the poststructuralist Foucault $(1980,1984)$ theorized about power relations, and Moje and Lewis (2007) conceptualized agency as the "strategic making and remaking of selves, identities, activities, cultural tools and resources, and histories, as embedded within relations of power" (p. 18).

Zimmerman (2014) explained that in the Western feminist discourse, agency and choice with respect to religious women are associated with liberal concepts of emancipation, and religion is perceived as being oppressive while modernity is attributed to secularism. Here, we reiterate our earlier position and refute the simplistic view of Muslim women as passive victims and one-dimensional characters who lack the agency to act, because of a false perception of religion. Muslim women, including Saudi women, can indeed be disempowered by the hegemonic male interpretation of the Quran and by the culture, though empowerment does not annihilate their agency at all. Kandiyoti (1989; cited in Shaheed, 1999, p. 62) declared that women in Muslim communities are "fully fledged 
actors" and their agency should be understood away from the oppositional agency. We believe that we should avoid using the secular prism to look at Muslim women's agency, just as we should stop perpetuating the idea that religion is the root cause of the lack of Muslim women's agency. We also believe that Muslim women's agency is enmeshed in the effects of language, knowledge, power, and history, with their race, ethnicity, gender, and religion.

We understand women's agency to be based on the intersectionality of sociocultural, economic, and political factors. The political decision to spread education to all in Saudi Arabia and open the door of scholarships to both genders has empowered women and clearly made a difference to their lives. Women also need to make a living and many have opted to work despite the limitations and restrictions. Acknowledging these factors supports the view that one cannot study the position of Saudi women only within the boundaries of religion discourses, laws, and practices.

Part and parcel with the discussion of Saudi women's agency is the understanding of two conceptualizations of the intersectionality between religion and agency. The first conceptualization comes from anthologist Mahmood (2005) who developed the notion of pious agency while working with Muslim women in Egypt. Mahmood (2005) maintained that the Egyptian women with whom she worked demonstrated "nonliberal pious agency" (p. 38). Mahmood showed how Egyptian women conform to religious ideals and transform themselves into virtuous Muslim subjects, which is a type of agency that goes against the assumptions of Western feminism as we have demonstrated earlier. Rinaldo's (2014) pious critical agency brings the discussion of the intersectionality of religion and agency to a full circle. Rinaldo (2014) worked extensively with Muslim women in Indonesia and argued that Indonesian women, through activism, demonstrate pious critical agency that is "the capacity to engage critically and publically with religious texts." Rinaldo (2014) contended that not only can Islam "be a resource for women's agency but that religion and feminism can intersect in surprising and unexpected ways" (p. 825). Rinaldo argued that when women use critical Islamic discourses, they show that pious and feminist subjectivities can intersect and overlap, and that Islam is the source of activism and authority for the women.

We propose that agency, including learner agency, is "socially oriented" (Toohey \& Norton, 2003, p. 59), and it entails actions that arise from deliberation and choice. It also involves the "strategic making and remaking of selves, identities, activities, relationships, cultural tools, and resources and histories, as embedded within relations of power" (Moje \& Lewis, 2007, p. 18).

\section{Compliant Agency}

To begin, we first need to define compliant agency, which is similar to what Mahmood (2001) introduced in her research and called docile agency that describes women's interaction with and embrace of religious traditions while still remaining bound to the marginalization that is prescribed by a particular interpretation of Islam. This type of agency is used to perpetuate and consecrate male domination. This particular perspective of agency is also closer to what we would call confinement agency, where women are confined to predefined spaces of agency that condemn them to a life of domesticity. In any case, compliant agency also describes women's interaction with and critical embrace of religious traditions to better themselves and pull away from seclusion. This is done by creating new spaces for agency that deconstruct the world made for them without their active participation.

Most of the reported agentic actions of Saudi women in Saudi Arabia can be classified as compliant agency; i.e., women choose to conform to religious teachings while taking action. Compliant agency does not mean that the women succumb completely and must comply with the religious teachings as prescribed by their culture, but rather, they would comply with the religious teachings that guarantee their autonomous actions, and they would adopt an interpretation of religious scriptures that grants them the power to act (for additional discussion see Mahmood, 2001, 2005; Muhanna, 2013). The discussions with the Saudi women participants in Mustafa's (2017) doctoral research revealed that they seemed to be cognizant of their social and familial roles and duties and of the gendered roles they were required to follow, and how these roles and duties were a part of who they were. At the same time, they tried to eschew the image of being confined by the roles and duties and explained that their actions stemmed from an understanding of how compliance and agency are not contradictory. Several narratives spoke of how the participants successfully created spaces for meaningful agency, and at the same time, how they could comply with Sharia and societal norms and duties. Mustafa's (2017) study showed that the Saudi women participants exercised what we call "agency maneuvers," where on one hand, the participants willfully subjected themselves to the ideas and practices of their society, considered by feminist scholars as subordination. On the other hand, the participants resisted and strategically exercised their agency so as to comply with society norms and Sharia'a parameters. One of the many opportunities of agency for the participating Saudi women was seen 
when discussing the reasons for choosing Saudi Arabia to learn English. The discussion was an epitome for compliant agency. The women complied with the religious teachings of Islam that calls for women to have guardianship if they wish to travel abroad for an extended period.

This agency of compliance is significant for two reasons: 1) it eschews the Western construct of the notion of agency that assumes that "people have access to choice and have the rationality and freedom to make decisions and exercise agency" (Parker 2005, p. 9), and it solidifies the fact that different cultural contexts construct agency in different forms, which was corroborated by Parker (2005) who noted that, in Indonesia, passivity is a form of agency; and 2) the agency maneuvers performed by the participants can be used to point to the false Western accusations of victimhood and marginalization of Muslim women, estranging the idea that agency is only synonymous with resistance. Abu-Lughod (1990) called this interpretation of agency (i.e., resistance) a "tendency to romanticize resistance," which would "read all forms of resistance as signs of the ineffectiveness of systems of power and of the resilience and creativity of the human spirit in its refusal to be dominated" (p. 42).

Ahearn (2006) posited: "[while] one can certainly understand the impulse behind equating agency with resistance, agency should not be reduced to it. Oppositional agency is only one of many forms of agency" (p. 115). Ortner (2001) complemented the notion of oppositional agency by introducing a second agency modality that she referred to as "agency of intention-of projects, purposes, desires" (p. 79), which is a notion of agency that is "centered more on the subjective individual's projects and desires" (VandenBroek, 2010, p. 486). In this study, it was clear that the exercise of agency was not completely instigated by the women's desire to oppose the hegemonic powers, but it also emerged from their needs, wants, and aspirations. Moreover, this agency was manifested through culturally meaningful and highly prized ways.

\section{Islamic Feminism(s)}

A critical premise of this paper is that a Western feminist framework for understanding Muslim women is inadequate, and Anglo-American Western models of feminism should not be used for considering Western views or studies of Muslim women in general, or the issues of Saudi women in particular. Nevertheless, the concept of feminism in the West is contested and lacks consensus (cf. Hawksworth \& Disch, 2016) who dedicated a large portion of their introductory chapter in the Oxford Handbook of Feminist Theory to discuss the contested nature of feminist theory). Shannon (2018) explained that orientalist stereotyping of Muslim women competed with other frameworks such as universal human rights to perpetuate the image of Muslim women as passive victims and subject to ongoing injustices. Thus, adopting an Islamic feminist perspective is more important than ever to fight the distorted image of Muslim women.

The notion of Islamic feminism has been under scrutiny since its inception and has faced challenges from two camps. The first contends that "Islam" and "feminism" are two polar terms and as such, Islamic feminism is an oxymoron. Haideh Moghissi (1999), a champion of this camp, asked "[h]ow could a religion which is based on gender hierarchy be adopted as the framework for struggle for gender democracy and women's equality with men?" (p. 125) Likewise, Ebadi, who was the first Iranian and Muslim woman to win the Nobel Prize, disagreed with the notion of Islamic feminism based on the assumption that women's rights and feminism are universal concepts (Naili, 2013). The other camp, however, sees Islamic feminism as an important and relevant movement in feminism as it critically reflects on Western feminism and how it perceives Islam, Muslim women as non-Western others, and male hegemonic dominance. Badran (2009), an advocate of this camp argued that "Islamic Feminism advocates women's rights, gender equality, and social justice using the Islamic Discourse as its paramount discourse, though not necessarily its only one" (p. 246). In this paper, we take a stand for Islamic feminism arguing that the opposing camp's discourse is not geared towards discussing feminism or women's rights, but it is a crusade to prove that Islam is misogynist, and that misogyny is at the root of women's oppression.

We also must clarify that the adjective "Islamic" used in Islamic feminism does not denote the "political Islam," which can also be referred to as "Islamist". Mir-Hossini and Tapper (2006) explained this by saying that when "Islamic" is attached to another "ism" it means finding inspiration and even legitimacy in Islamic history and textual resources. Thus, according to Badran (2009), Islamic feminism is "feminist discourse and practice articulated within an Islamic paradigm" (1). Mir-Hossini (2006) elaborated that Islamic feminism denotes:

"a new consciousness, a new way of thinking, a gender discourse that was feminist in its aspiration and demands, yet Islamic in its language and source of legitimacy" (p. 640).

Islamic feminism does not seek to abolish Islam as the root cause of women's injustice; rather, it argues that the solution to ensuring women's justice and empowerment lies in re-interpreting the Quran, which is said to hold the principles of equality and justice. Islamic feminists believe that the current practices against women are the 
result of a corrupt patriarchal interpretation of the Quran, and societal practices and customs. Abou-Bakr (2011) captured the essence of the Islamic feminism project eloquently by reporting that Islamic feminism is:

"a continuous attempt to un-interpret [emphasis added] past gender biased readings done by male jurists and to offer alternative new perspectives towards justice and equality within Islam itself" (p. 1).

Shifting our attention to Saudi Arabia, the context of this paper, we highlight that within Saudi Arabia, two types of Islamic feminists can be found. The first, labeled by Al-Rasheed (2013) as Liberal Islamists, are described as:

"Highly educated women who are critical of religious restrictions on their lives... some are liberal in their education and look. They subscribe to international discourse on gender and human rights. Their feminism is grounded in a cosmopolitan outlook... They do not see any contradiction between the global human rights discourse on gender and moderate Islam" (pp. 135-36).

The other group, labeled "modern Islamists," celebrate Islamic solutions to gender issues in Saudi Arabia and:

"situate emancipation within Islamic framework, and continue to invoke the Islamic tradition as an ideal source to draw on in order to gain more rights in Saudi society. Their reference is not global international discourse on gender equality, but ahistorical Islam... they see Islam as the framework that should guide their emancipation. They do not call for equality with men but for complementarity, as they see themselves contributing to society in specific ways that do not negate their identity as women" (Al-Rasheed, 2013, pp. 136-137).

Research projects attempting to investigate an issue with participating Saudi women will undoubtedly benefit from Islamic feminism to explore where the Saudi women locate themselves vis-á-vis Islamic feminism, and to uncover the feminist and religious aspects of their identity. Moreover, the adoption of Islamic feminism will provide a voice against the essentialism of the Muslimwoman (Cooke 2007). We support Tohidi's (2006) argument that Islamic feminism is an "inevitable and positive component of the ongoing change, reform, and development of Muslim societies as they face modernity" (639). Nevertheless, we would like to highlight that our position echoes that of Moghissi (1999), in that an over-emphasizing of Islamic feminism primarily serves "the viewpoints of the regions' Muslim female elites" (p. 146), and denies the non-Muslim women who are trying to voice their concerns in the same region, while also denying the views of Saudi women who are happy to embrace a Western view of feminism. We cannot assume that because Saudi women are Muslim their views ought to emanate from an Islamic angle.

\section{What Does This Mean for Researchers?}

Researchers need to be cognizant of what Mustafa (2017) refers to as "sampling and literature manipulation" when researching Saudi Arabia and Saudi women. Sampling and literature manipulation denote the process of cherry picking a certain type of Saudi women or a certain portrait of Saudi Arabia that represent fractional truth about the whole setting and that best serve the researcher's purposes or that the literature abounds with references that support the researcher's claim. In her essay, "The politics of 'unveiling Saudi women'," Le Renard (2014) spoke of the state's deliberate actions to promote unveiled, successful Saudi women in media outlets intended for the West, and explained that such actions ignore the existence of women with other social and political orientations, leading to an uneven representation of Saudi women. Thus, social science researchers must unveil the "research invisibility" of Saudi women and strive to present a true representation of them all. In other words, research should be inclusive and not focused on 'Super or Suppressed" women only.

In addition to the aforementioned, many studies targeting Saudi women use a familiar emancipatory tone and depict the state regulations as an evil that needs to be eradicated so that Saudi women can have more room to be free. Many contemporary writers and commenters on the Saudi women affair (e.g., Doumato, 2010; al-Sharif, 2017; Eltahawy, 2015; Al-Rasheed, 2013, 2015; Kechichian, 2013, among others) still use the emancipatory tone to paint a dim picture of the status of Saudi women and their relationship with the Saudi government. However, critical social research dictates that researchers need to look for the full picture and understand the ontological and epistemological backgrounds of the writers before embracing their ideas. Saudi Arabia and the status of Saudi women is in a continuous state of flux; and one size fits all approach is not sufficient. While we argue that Islamic feminism should not be ignored when conducting research on the status and roles of Saudi Women, we also acknowledge that it cannot be the only theoretical framework appropriate for such an endeavor. A proliferation of conceptual frameworks would allow research to study agency from different angles and perspectives and avoid dogmatic essentialism. This should lead to a deeper and more enlightened understanding of women's conditions and role in a context such as Saudi Arabia.

The other implication for research is concerned with the notion of intersectionality. The Saudi women (Mustafa, 
2017) narrated stories about how power relations were reflected in their social lives, influenced their decisions to learn English, and had an impact on their identities. One of the conclusions was about the importance of understanding the learners from the perspectives of their communities. Since people have multi-dimensional and complex lives, the inequalities are never due to a single, distinct factor. Instead, the outcomes are from intersections at different social locations, power relations, and experiences (Hankivsky, 2014). Researchers need to include the theory of intersectionality in interpreting their results. According to Morris and Bunjun (2007), "It is important to acknowledge multiple realities, and not to 'essentialize' any group, that is, not to treat any group as if all its members are exactly the same and have the same experiences, view and priorities" (p. 5). We call upon researchers interested in investigating Saudi women to consider the myriad linguistic, cultural, ethnic, religious, and racial differences that exist among the women, and not to presume that a single Saudi woman learner might be speaking for all Saudi women.

This study is significant not only because it tackles the paucity of research that investigates Saudi women identities and sense of agency in Saudi Arabia, but because it also uses Islamic feminism as a theoretical underpinning; a matter most research in the MENA region neglect or fail to apply; and we hope that social researchers interested in researching Saudi women or Saudi Arabia to take it a s a springboard to their studies.

\section{References}

Abou-Bakr, O. (2011). What's done can be un-done: Un-interpreting gender-hierarchy in Quranic Exegesis. Paper presented at the 12th Mediterranean research Meeting, Florence, Italy, pp. 1-17.

Abu-Lughod, L. (1990). The romance of resistance: Tracing transformations of power through Bedouin women. American Ethnologist, 17(1), 41-55. https://doi.org/10.1525/ae.1990.17.1.02a00030

Ahearn, L. (2001). Language and agency. Annual Review of Anthropology, 30, 109-37. https://doi.org/10.1146/ annurev.anthro.30.1.109

Ahearn, L. (2012). Living language: An introduction to linguistic anthropology. Oxford: Wiley-Blackwell.

Alhargan, R. A. (2012). Saudi Arabia: Civil rights and local actros. Middle East Policy, 19(1), 126-139. https://doi.org/10.1111/j.1475-4967.2012.00529.x

Al-Rasheed, M. (2013). The most masculine state: Gender, politics, and religion in Saudi Arabia. Cambridge: Cambridge University Press. https://doi.org/10.1017/CBO9781139015363

al-Sharif, M. (2017). Daring to drive: A Saudi woman's awakening. New York, NY: Simon \& Schuster.

Al-Sudairy, H. T. (2017). Modern woman in the Kingdom of Saudi Arabia: Rights, challenges and achievements. New Castle Upon Tyne: Cambridge Scholars Publishing.

Badran, M. (2009). Feminism in Islam: Secular and religious convergences. Oxford: Oneworld Publications.

Bakhtin, M. M. (1986). Speech genres and other late essays. Austin: University of Texas Press.

Beydoun, K. A. (2011). Fast tracking women into parliamentary seats in the Arab world. Southwestern Journal of International Law, 64, 63-110.

Bourdieu, P. (1984). Distinction: A social critique of the judgment of taste. Cambridge, MA: Harvard University Press.

Bucholtz, M. (2003). Sociolinguistic nostalgia and authentification of identity. Journal of Sociolinguistics, 7 , 398-416. https://doi.org/10.1111/1467-9481.00232

Butler, J. (1999/2006). Gender trouble: Feminism and the subversion of identity. New York: Routledge.

Cooke, M. (2007). The Muslimwoman. Contemporary Islam, 1(2), 139-154. https://doi.org/10.1007/s11562-007-0013-z

Curtis, E. E. (2010). Encyclopedia of Muslim-American history. U.S.A: Library of American History.

Delong-Bas, N. (2004). Wahhabi Islam: From revival and reform to global jihad. New York, NY: I.B. Tauris \& Co. Ltd.

Denman, B., \& Hilal, K. (2011). From barriers to bridges: An investigation of Saudi student mobility $\begin{array}{lllll}\text { (2006-2009). International Review } & \text { 299-318. }\end{array}$ https://doi.org/10.1007/s11159-011-9221-0

Deo, N. (2006). Is globalization our friend? Women's allies in the developing world. Current History, 105(689), 105-111. 
Doumato, E. A. (2010). Saudi Arabia. In S. Kelly, \& J. Breslin (Eds.), Women's rights in the Middle East and North Africa: Progress amid resistance (pp. 425-459). New York, NY: Freedom House.

Duff, P. (2012). Identity, agency, and SLA. In A. Mackey, \& S. Gass (Eds.), Handbook of second language acquisition (pp. 410-426). London: Routledge.

Eltahawy, M. (2015). Headscarves and hymens: Why the Middle East needs a sexual revolution. New York, NY: Farrar, Straus \& Giroux.

Giddens, A. (1984). The constitution of society: Outline of the theory of structuration. Cambridge: Polity Press.

Haas, M. L. (2014). The United States and the Arab spring: Threats and opportunities in a revolutionary era. Boulder, CO: Westview Press.

Hamdan, A. (2005). Women and education in Saudi Arabia: Challenges and achievements. International Education Journal, 6(1), 42-64.

Hawkesworth, M., \& Disch, L. (2016). Introduction. Feminist Theory: Transforming the known world. In L. Disch, \& M. Hawkesworth (Eds.), Oxford Handbook of Feminist Theory (pp. 1-15). New York, NY: Oxford University Press.

Hekman, S. (2013). Feminism, identity and difference. London: Routledge. https://doi.org/10.4324/9781315039688

Le Renard, A. (2014). The politics of "unveiling Saudi women": Between postcolonial fantasies and the surveillance state. Jadaliyya. Retrieved from http://www.jadaliyya.com/pages/index/20259/the-politics-ofunveiling-saudi-women_between-post

Littrell, R. F., \& Bertsch, A. (2013). Traditional and contemporary status of women in the patriarchal belt. Equality, Diversity and Inclusion, 32(3), 310-324. https://doi.org/10.1108/EDI-12-2012-0122

Mahmood, S. (2001). Feminist theory, embodiment, and the docile agent: Some reflections on the Egyptian Islamic revival. Cultural Anthropology, 6(2), 202-236. https://doi.org/10.1525/can.2001.16.2.202

Mahmood, S. (2005). Politics of piety: Islamic revival and the feminist subject. Princeton: Princeton University Press.

Miller-Rosser, K, Chapman, Y., \& Francis, K. (2006). Historical, cultural and contemporary influences on the status of women in nursing in Saudi Arabia. Online Journal of Issues in Nursing, 11(3).

Mir-Hosseini, Z. (2006). Muslim women's quest for Equality: Between Islamic law and feminism. Critical Inquiry, 32, 629-645.

Mir-Hosseini, Z., \& Tapper, R. (2006). Islam and democracy in Iran: Eshkevari and the quest for reform. London: I.B. Tauris.

Moghissi, H. (1999). Feminism and Islamic fundamentalism: The limits of postmodern analysis. London: Zed Books.

Moje, E. B., \& Lewis, C. (2007). Examining opportunities to learn literacy: The role of critical sociocultural literacy research. In C. J. Lewis, P. Enciso, \& E. B. Moje (Eds.), Reframing sociocultural research on literacy: Identity, agency, and power, (pp. 15-48). Mahwah, NJ: Lawrence Erlbaum Associates.

Morris, M., \& Bunjun, B. (2007). Using intersectional feminist frameworks in research. Ottawa: Canadian Research Institute for the Advancement of Women.

Muhanna, A. (2013). Agency and Gender in Gaza: Masculinity, femininity and family during the second Intifada. Farnham, Surrey: Ashgate.

Mustafa, R. F. (2017). The impact of learning English as a foreign language on the identity and sense of agency of Saudi women. Unpublished thesis, University of Exeter.

Naili, H. (2013). Shirin Ebadi urges Arab women to keep the faith. Retrieved from http://womensenews.org/2013/04/shirin-ebadi-urges-arab-women-keep-the-faith/

Ochsenwald, W. (1981). Saudi Arabia and the Islamic revival. International Journal of Middle East Studies, 13(3), 271-286. https://doi.org/10.1017/S0020743800053423

Oliver, H. J. (2004). The 'Wahabi' myth: Dispelling prevalent fallaciesand the fictitious link with Bin Laden. Toronto: TROID Publications.

Ortner, S. (2001). Specifying Agency: The comaroffs and their critics. Interventions, 3(1), 76-84. 
https://doi.org/10.1080/13698010020027038

Parker, L. (2005). Introduction. The agency of women in Asia. In L. Parker (Ed.), The agency of women in Asia, (pp. 1-25). Singapore: Marshall Cavendish International.

Rinaldo, R. (2014). Pious and critical: Muslim women activists and the question of agency. Gender and Society, 28(6), 824-846. https://doi.org/10.1177/0891243214549352

Sahly, A. (2016). Examining presence and influence of linguistic characteristics in the Twitter discourse surrounding the women's right to drive movement in Saudi Arabia. Unpublished thesis, University of Central Florida.

Shaheed, F. (1999). Constructing identities: Culture, women's agency and the Muslim world. International Social Science Journal, 51, 61-73. https://doi.org/10.1111/1468-2451.00177

Shannon, K. J. (2018). U.S. Foreign Policy and Muslim Women's Human Rights. Philadelphia: University of Pennsylvania Press. https://doi.org/10.9783/9780812294538

Tohidi, N. (2006). Islamic feminism: Women negotiating patriarchy and modernity in Iran. In I. Abu-Rabi (Ed.), The Blackwell companion of contemporary Islamic thought (pp. 624-643). Oxford, UK: Blackwell Publishing. https://doi.org/10.1002/9780470996188.ch36

Toohey, K., \& Norton, B. (2003). Learner autonomy as agency in sociocultural settings. In D. Palfreyman \& R. C. Smith (Eds.), Learner autonomy across cultures: Language education perspectives (pp. 58-72). New York: Palgrave Macmillan. https://doi.org/10.1057/9780230504684_4

VandenBroek, A. K. (2010). Agency and Practice Theory. In H. J. Birx (Ed.), $21^{\text {st }}$ Century anthropology: A reference book (Vol. 1, pp. 480-487). Thousand Oaks, CA: Sage Publications. https://doi.org/10.4135/9781412979283.n49

Vygotsky, L. S. (1978). Mind in society: The development of higher psychological processes. Cambridge, Mass: Harvard University Press.

Weedon, C. (1997). Feminist practice and poststructuralist theory (2nd ed.). Oxford: Blackwell.

Yamani, M. (2000). Changed identities: The challenge of the new generation in Saudi Arabia. London: The Royal Institute of International Affairs. Chameleon Press.

Yamani, M. (2005). The challenge of globalization in Saudi Arabia. In F. Nouraie-Simone (Ed.), On shifting ground: Middle eastern women in the global era (pp.80-90). New York, NY: The Feminist Press at the City University of New York.

Zarabozo, J. M. (2003). The life, teachings and influence of Muhammed Ibn Abdul Wahhab. Riyadh: The Ministry of Islamic Affairs, Endowment, Da'wah and Guidance.

Zimmerman, D. D. (2014). Young Arab Muslim women's agency challenging Western feminism. Journal of Women and Social Work, 30(2), 145-157. https://doi.org/10.1177/0886109914546126

\section{Copyrights}

Copyright for this article is retained by the author(s), with first publication rights granted to the journal.

This is an open-access article distributed under the terms and conditions of the Creative Commons Attribution license (http://creativecommons.org/licenses/by/4.0/). 